\title{
Climate change impacts on Central Asian water resources
}

\author{
M. Malsy, T. Aus der Beek, S. Eisner, and M. Flörke \\ Center for Environmental Systems Research, University of Kassel, Wilhelmshöher Allee 47, 34109 Kassel, Germany \\ Correspondence to: M. Malsy (malsy @usf.uni-kassel.de)
}

Received: 31 January 2012 - Revised: 28 August 2012 - Accepted: 11 October 2012 - Published: 13 December 2012

\begin{abstract}
Central Asia is in large parts dominated by low precipitation and, consequentially, by low water availability. Therefore, changes of natural water resources induced by climate change are of high interest. The aim of this study is to analyse the potential impact of climate change on Central Asian water resources until the end of the 21 st century and to point out the main affected regions. Thus, simulations with the large-scale hydrology model WaterGAP3 for the baseline and scenario periods were performed with outputs from three General Circulation Models (GCMs: ECHAM5, IPSLCM4, and CNRM-CM3) and two IPCC-SRES emission scenarios (A2 and B1). The results show that mean modelled annual water availability increases for all scenarios and GCMs while CNRM-CM3 induces the wettest water situation for the 2085s and ECHAM5 the lowest water availability. Furthermore, robust trends to wetter or dryer conditions could be found for many basins. A seasonal shift of mean modelled water availability could be derived for ECHAM5 which does not show a second peak during summer. The application of daily input data showed no improvement of modelled monthly river discharges for most Central Asian basins compared to monthly input data.
\end{abstract}

\section{Introduction}

Large parts of Central Asia feature arid to semi-arid conditions and are therefore of high interest for hydrological studies, as water scarcity often limits the development of human, ecological, and industrial resources. However, not only climate change induced water problems, such as permafrost and glacier melting (Marchenko et al., 2007) and increased evapotranspiration (Yu et al., 2003) prevail in Central Asia, but also overexploitation of existing water resources (aus der Beek et al., 2011; Bucknall et al., 2003), transboundary water conflicts (ICG, 2002), failure of post-soviet water management strategies (O'Hara, 2000), and many more (EDB, 2009; Lioubimtseva and Henebry, 2009).

Within this integrated model study the hydrological and water use model WaterGAP3 (Water - Global Assessment and Prognosis) is applied to all river basins located in Kazakhstan, Kyrgyzstan, Tajikistan, Turkmenistan, Uzbekistan, Southern Russia, North-Western China, and Mongolia in five arc minutes spatial resolution $(\sim 6 \times 9 \mathrm{~km}$ per grid cell). Furthermore, an overview of the Central Asian water resources of the last three decades is given. To verify the plausibility of the model results, simulated river discharge is compared to observed river discharge. At this point, the impact of daily climate input data compared to monthly climate input data on modelled monthly river discharge is examined. Following the successful validation of the model results, transient biascorrected climate change projections are being applied to estimate their impact on the water resources of Central Asia. Monthly fields of precipitation, radiation and air temperature output from the Global Circulation Models (GCMs) CNRMCM3, ECHAM5, and IPSL-CM4 for the SRES-IPCC scenarios A2 and B1 (IPCC, 2000) are used to drive WaterGAP3 to calculate potential changes in future local water resources. Thus, the model results also provide further insight into the range and uncertainty of climate change impacts when applying opposing climate models and scenarios. Menzel et al. (2008) analysed precipitation trends in a study for Mongolia. Even if water availability was not the focus of this study, but runoff generation, it is of high interest. They found an increase with ECHAM5 in the Middle and East of Mongolia with up to $20 \%$ more precipitation while the other parts mostly show small changes in the B1 scenario. For the A1B scenario the western and southern parts of Mongolia showed a decrease in runoff generation. 


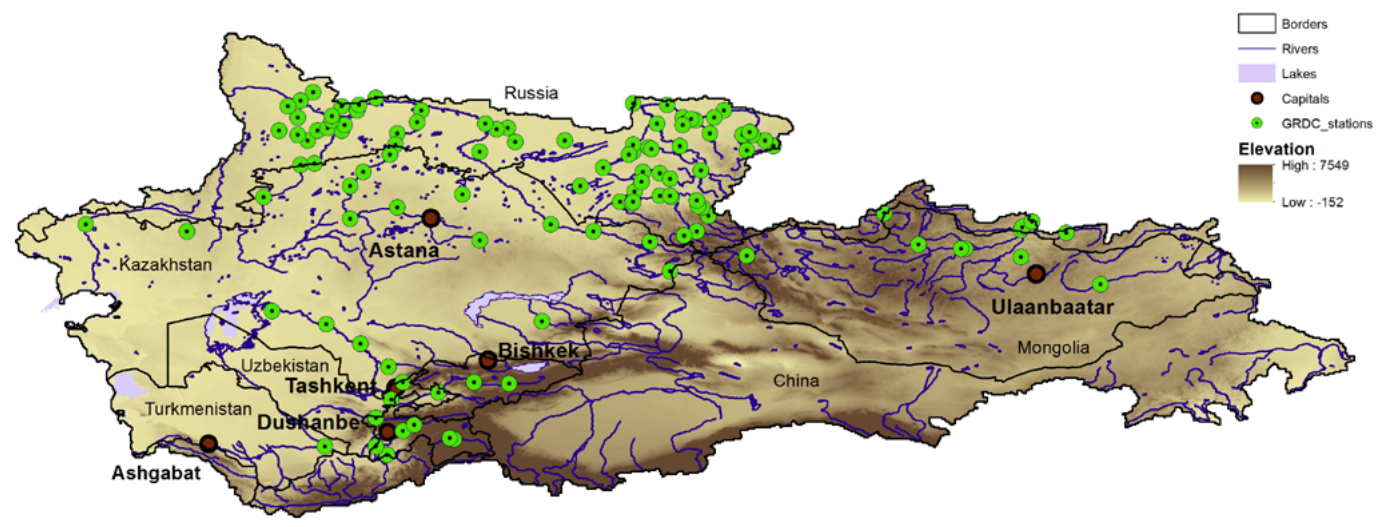

Fig. 1. Study Region of Central Asia with GRDC (Global Runoff Data Center) stations.

\section{Methods and study region}

\subsection{Study region}

This study focuses on the region of Central Asia whereas this region is not defined by political borders but through the extent of river basins. Therefore, the term Central Asia contains the countries of Kazakhstan, Kyrgyzstan, Mongolia, Tajikistan, Turkmenistan and Uzbekistan entirely as well as parts of Russia and China (cp. Cowan, 2007) (see Fig. 1). The study region is confined in the South (-West) by the mountains of Kopet Dag and Pamir, and with the Caspian Sea as western border. Moving on eastwards from the Pamir, the southern border is determined by the Kunlun Shan and Altun Shan mountains. Next to this mountain chain the Tarim basin with the desert of Taklamakan followed by Mongol Shan and Gobi desert can be found. The northern boundary is determined by the south Siberian lowlands with its large plain areas. The middle parts in the West (Kazakhstan) and East (Mongolia) are dominated by the Eurasian Steppe. The driest part of the study region is located in the desert regions of Gobi, Taklamakan, Karakum and Kyzyl Kum while the mountainous regions of Pamir, Altai, Alatau as well as south Siberia have the highest annual precipitation amounts. Especially, the downstream arid lowlands are highly reliant on water provision from the mountainous regions (Hagg et al., 2007). The biggest water bodies in the study region are the rivers $\mathrm{Ob}$ (North-Northeast Kazakhstan) with its tributaries Irtysh and Tobol, as well as Ural (West-Northwest Kazakhstan), Amu Darya (Fountain head in Pamir Mountains, then runs Turkmenistan and Uzbekistan to the Aral Sea), Syr Darya (Origin in Tien-Shan Mountains, then runs through Kyrgyzstan, Uzbekistan and Kazakhstan to the Aral Sea), Tarim (Northwest-China) as well as the lakes Balkhash (East-Kazakhstan), Issyk Kul (Kyrgyzstan) and Aral Sea (Border of Kazakhstan and Uzbekistan). In summary, the study region is topographically dominated by the Eurasian Steppe and additionally by mountains and deserts (Worden and Savada, 1991; Curtis, 1997).
Overall, the study region features a spatial extent of $\sim 10$ million $\mathrm{km}^{2}$ with an elevation range from below sea level in the Turpan Depression $(-152 \mathrm{~m})$ and $(-135 \mathrm{~m})$ in the Aral-Caspian Depression up to $7500 \mathrm{~m}$ in the high mountainous regions of Pamir and Tien-Shan. Due to the continental and mainly arid to semi-arid climate the study region has a high temperature amplitude from $-45^{\circ} \mathrm{C}$ in winter up to $40^{\circ} \mathrm{C}$ during the summer. Although the study region is sparsely populated in the most parts, some regions - such as the Aral Sea basin - are heavily influenced by anthropogenic water uses (e.g. water abstractions for agriculture).

\subsection{Data and method}

Within this study the large-scale hydrology and water use model WaterGAP3 has been applied, which is a further development of the global model WaterGAP2 (Alcamo et al., 2003; Döll et al., 2003). WaterGAP3 still can operate on the global scale, whereas in this study a Central Asian landmask derived from river basins has been applied. In addition to the increase in spatial resolution from $0.5^{\circ}(\sim 50 \mathrm{~km} \times 50 \mathrm{~km})$ to $5^{\prime}(\sim 6 \mathrm{~km} \times 9 \mathrm{~km})$ (Verzano, 2009) also some hydrological process descriptions have been improved in WaterGAP3, such as snow related processes (Verzano and Menzel, 2009), flow velocity (Schulze et al., 2005), and water use (aus der Beek et al., 2010; Flörke et al., 2012). However, as this study focuses on the impact of climate change on available water resources, water use will not further be considered herein, but will follow in a future study. Monthly water fluxes for each of the 167600 Central Asian grid cells forming 1536 basins were calculated taking into account spatially distributed physiographic information on elevation, slope, hydrogeology, land cover and soil properties, as well as location and extent of lakes, wetlands, and reservoirs. It has to be mentioned that many of the small basins are closed depressions. The upstream/downstream relationship among the grid cells is defined by a global drainage direction map (DDM) which indicates the drainage direction of surface water (Lehner et al., 2008). If only monthly climate input is 
available WaterGAP3 internally calculates the water balance of each grid cell on daily time steps. Therefore, all climate input, except precipitation, is interpolated with cubic splines to daily values. In terms of precipitation the model computes pseudo-daily time series from the number of rain days using a Markov chain algorithm (Geng et al., 1986).

As climate input data for the baseline period 1971 to 2000 the WATCH forcing data (WFD), generated within the European Union-Framework Six (EU-FP6) - WATer and global CHange Project (WATCH), was used. This halfdegree global climate dataset was derived from ERA-40 reanalysis data and is available in daily time steps for the time period 1958 to 2001. For detailed information on the WATCH forcing data see Weedon et al. $(2010,2011)$. As radiation input shortwave derived from CRU data was used. Malsy et al. (2011) have shown that the WATCH forcing dataset is suitable for application in Central Asia.

The climate change projections for the 21st century were extracted from the WATCH driving data. This dataset is available for two IPCC-SRES scenarios (A2 and B1) and for three GCMs; IPSL-CM4 (Institute Pierre Simon Laplace, France), ECHAM5 (Max Planck Institute for Meteorology, Germany) and CNRM-CM3 (Centre National de Recherches Météorologiques, France). The WATCH driving data provides transient bias-corrected scenarios and is available with a daily temporal and a half-degree spatial resolution from 1960 to 2100 . For further information on the WATCH driving dataset and the statistical bias correction see Hagemann et al. (2011) and Piani et al. (2010).

All climate datasets have been rescaled from half-degree to five arc minute spatial resolution. The transient and biascorrected climate scenarios have been divided into 30-yr time slices, i.e. 2011-2040, 2021-2050, ..., 2071-2100, for a better comparison to the 1971-2000 baseline results. The baseline time period has been simulated with daily and monthly climate data input to explore the impact of daily input data on the simulated monthly water fluxes. For this reason the daily WFD data was aggregated to monthly values.

The performance of the model results was evaluated by comparing modelled to observed river discharge for 73 valid stations in Central Asia available from the Global Runoff Data Center (GRDC) database. Since some GRDC stations records do not cover the entire baseline period, only parts of the baseline could be validated. The location of the GRDC gauging stations shows a concentration in the northern part of the study region at the Russian border. Especially, the arid parts lack gauging station data, which is shown in Fig. 1. In this region only a few runoff stations with often short time series observations are available for model calibration and validation. Also, climate data is less reliable in these regions, which leads to interpolation inconsistencies, as often only few climate stations are available.

For the scenario period the influence of climate change on the water fluxes, e.g. water availability has been examined. First, the decadal trend of mean annual water availability in
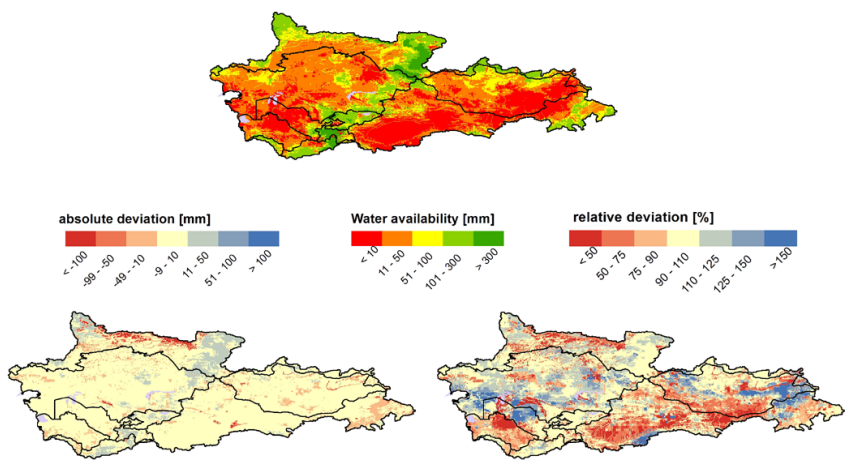

Fig. 2. Modelled annual water availability based on monthly input data (top); alongside absolute and relative deviation between monthly and daily data input (baseline period 1971-2000).

comparison to the baseline results has been analysed. Furthermore, modelled water availability for 2071-2100 (2085s) has been compared with the baseline water availability on river basin level to assess spatial changes. Here, the robustness of trends in water availability - three GCMS pointing into the same direction of change - has been analysed. The threshold for relative changes has been set to $\pm 5 \%$ and for absolute changes to $\pm 5 \mathrm{~mm}$. Finally, changes not only in mean annual water availability but also seasonal variability are of high interest. On this account, the monthly variability for three GCMs and two IPCC-SRES scenarios (2071-2100) have been simulated and compared with the baseline period (1971-2000).

\section{Results and discussion}

\subsection{Modelling current water resources in Central Asia}

Central Asia features large areas with low precipitation and therefore limited water resources, which can be observed in the modelled annual water availability for the time period 1971-2000 (cp. Fig. 2). The big desert regions, i.e., Gobi, Karakum, and Taklamakan, show mean annual water availability below $10 \mathrm{~mm}$. Predominant westerly winds, lee side effects and orographic precipitation patterns are the reasons for this low precipitation (e.g. Taklamakan desert). In contrast, there are mountainous regions, e.g., the Pamir and Altai mountains, with high precipitation and mean annual water availability of more than $1200 \mathrm{~mm}$. The mean water availability in the study region is $63 \mathrm{~mm}$ and $66 \mathrm{~mm}$ as modelled with monthly and daily data input, respectively. Here, the predominant patterns of modelled annual water availability are very similar for monthly and daily data input.

The highest deviations for absolute values between daily and monthly data input are in the mountainous regions of Central Asia, i.e., Pamir, Dzungarian Alatau, and Altai, as well as southern Siberia (Fig. 2). On the one hand, model results with monthly input data result in wetter conditions in 


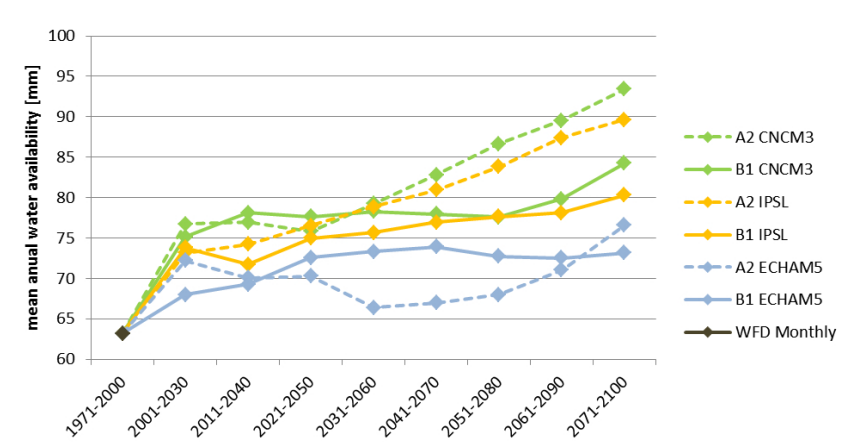

Fig. 3. Modelled decadal mean annual water availability from 1971 to 2100 (Baseline period 1971-2000 with WFD, scenario period 2001-2100 with three GCMs and two scenarios).

the mountain regions. On the other hand, model results with daily input data show higher water availability in the North of the study region (Siberia). In contrast, the examination of relative differences leads to different spatial patterns. The reason for these differences can be found in the input data; daily input data result in wetter conditions in the southern desert parts, i.e., Gobi, Taklamakan, and Karakum, as well as again at the Siberian border in the North. Monthly data is wetter around the Aral Sea and in eastern part of Mongolia.

Whereas the mean modelled annual water availability slightly differs between daily and monthly input, more effects can be found in the modelled hydrographs of river discharge and its model efficiency evaluation. The NashSutcliffe Efficiency (NSE) and coefficient of determination $\left(R^{2}\right)$ for modelled monthly river discharge show higher, and thus better values with monthly (NSE $0.45, R^{2} 0.65$ ) than daily (NSE $0.39, R^{2} 0.56$ ) input data. Generally, the model application is suitable for the entire study region with a mean NSE of 0.45 . Not only the level of the efficiency criteria is higher with monthly data input, also more stations were modelled validly (73 to 60). Mostly, the river runoff peaks are overestimated with daily input data, which leads to overestimated runoff generation and, hence, to lower efficiency criteria (Krause et al., 2005). Further, the base flow appears higher for daily input data. In many cases, this is caused by rather small peaks in autumn, which lead to a slower transition from peak to low flow. It has to be mentioned that some regions and rivers which are heavily influenced by anthropogenic water abstractions such as Amu Darya and Syr Darya cannot be simulated accurately because the model setup within this study simulates the water fluxes only with natural conditions (i.e., water abstraction is not considered). Beside this, also the observed runoff data may include uncertainties - for example measurement errors.

As shown above, daily data input does not improve the results for modelled monthly river discharge. One reason for this could be that the model structure and the representation of evapotranspiration processes was developed for monthly data input. Hence, further adaptation of the model to daily input data might improve the results.

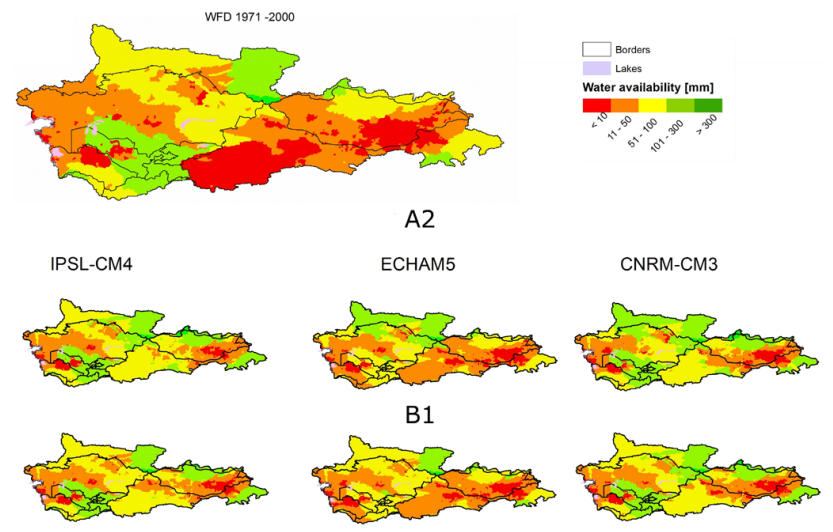

Fig. 4. Modelled annual average water availability on river basin level for the baseline period 1971-2000 and for the scenario time period 2071-2100, separately shown for each GCM/emission scenario combination.

\subsection{Potential future development of Central Asian water resources}

The simulation of the potential future development of Central Asian water resources has been carried out with the WATCH driving data (see Sect. 2.2). While for the baseline a small decrease between the time periods 1961-1990 and 1971$2000(64 \mathrm{~mm}$ to $63 \mathrm{~mm}$ ) was noticed, an increase of mean annual water availability for each scenario and GCM until 2100 compared to the baseline was found. For both scenarios, $\mathrm{A} 2$ and $\mathrm{B} 1, \mathrm{CNRM}-\mathrm{CM} 3$ shows the highest increase in water availability and ECHAM5 the lowest.

It has to be mentioned that the baseline values were computed with the ERA-40 corrected WFD and not with the respective GCM baseline. This was necessary to calibrate WaterGAP3 accurately, because the GCM baselines are too wet and lead to overestimated calibration parameters. For a detailed description of the calibration method of WaterGAP see Alcamo et al. (2003). Thus, even though WATCH forcing (until 2001) and driving (scenarios) data are supposed to be transient and bias-corrected, an offset between the observed WFD data (time period 1971-2000) and the first scenario period 2001-2030 (see Fig. 3) exists. While CNRM-CM3 and IPSL-CM4 show a constant increase in mean water availability for the study region, ECHAM5 causes firstly a decrease which turns from the 2045s to an increase until the end of the 21 st century (scenario A2). This is induced by an increasing precipitation input in the scenario data during the 21 st century, as precipitation is the main driver of the water cycle. In general, it can be determined that the differences between the IPCC-SRES scenarios (up to $9 \mathrm{~mm}$ in 2071-2100) is smaller than between the GCMs (up to $17 \mathrm{~mm}$ in 2071-2100). Furthermore, the impact of the A2 scenario is stronger than of B1 except for the ECHAM5 driven simulations. Here, the B1 scenario results are well above the A2 outcomes until the last phase (2071-2100). This is in agreement with Zwolsman et 


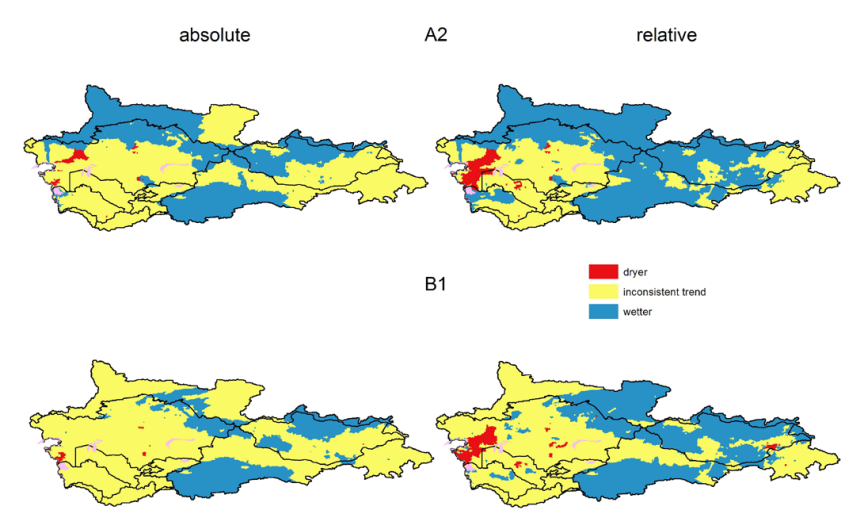

Fig. 5. Robustness of trends (all GCMs show the same direction of change; threshold of $5 \%$ for the relative trends and $5 \mathrm{~mm}$ for absolute trends) in modelled water availability for the scenario period 2071-2100 and the two emission scenarios A2 and B1.

al. (2011) who detected also stronger impacts under the A2 than the B1 scenario.

Looking at the spatial distribution of mean modelled water availability the following picture emerges (Fig. 4). Compared with the baseline the $\mathrm{Ob}$ river basin and the Altai Mountains river basins remain with high water availability in all GCM/scenario combinations. For the Tobol river basin in the north western part of Central Asia the A2 scenario leads to an increase of water availability with ECHAM5 as well as CNRM-CM3. This trend cannot be found for IPSL-CM4 and for the B1 scenario. In the western part in the Aral-Caspian depression water availability stays in dry conditions with all GCM/scenario combinations. In contrast to the Karakum and Gobi Desert, where all three GCMs and scenarios project ongoing dry conditions, the Tarim basin within the Taklamakan desert gets wetter with the IPS1-CM4 and CNRM-CM3 and less wet with ECHAM5. In the Amu Darya and Syr Darya basins only ECHAM5 shows a decrease in water availability. Generally, in relation to the baseline (1971-2000) the middle and middle-eastern parts of the study region are mostly affected by increasing natural water availability (e.g. Tarim basin, Selenga basin).

In contrast, the biggest change to dryer conditions can be found in the Aral Caspian Depression within all models and scenario combinations. Also, parts of the Gobi Desert in Southeast Mongolia, Dzungaria and middlesouthern Turkmenistan show decreasing trends, particularly with ECHAM5. IPSL-CM4 shows for nearly entire Mongolia an increasing trend and CNRM-CM3 for the North and West. ECHAM5 leads to a decrease in water availability in the Southeast (Gobi Desert) and to an increase in the Altai Mountains. In comparison, Ragab and Prudhomme (2002) projected for the Aral Sea basin an increasing precipitation by $5-20 \%$ in summer and winter, and also Batimaa et al. (2011) expected a sharp increase of winter precipitation for Mongolia which leads in combination with increasing air

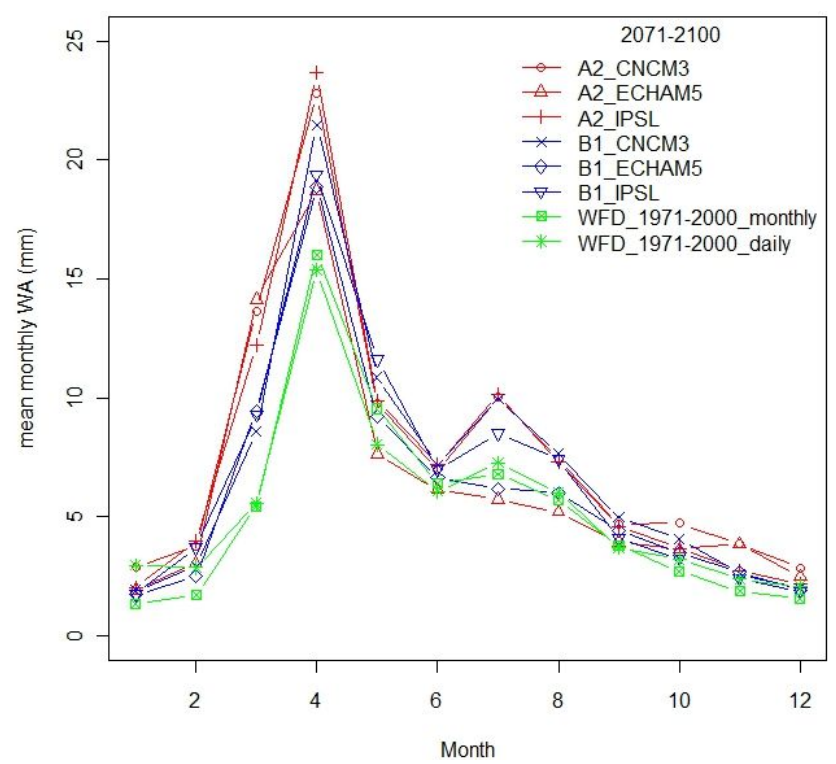

Fig. 6. Seasonal variability of modelled monthly water availability (WA) for time period 2071-2100 in comparison to baseline time period (1971-2000).

temperature to changes in evapotranspiration and water availability.

The robustness of trends (Fig. 5) confirms the abovenamed changes in water availability. Modelled water availability (absolute values) shows an increasing trend for both scenarios in the south of the study region (Chinese Xinjiang region), for the north of Mongolia and the Mongolian Altai, and in the A2 scenario also for the Tobol and Ural basin. A decreasing trend can be found in the Aral Caspian Depression, North-Northwest and Southwest of the Aral Sea. For relative values the same patterns can be found, whereas an increasing trend also in Russian Altai and the Ob river basin can be observed.

Ragab and Prudhomme (2002) expected a change in water availability due to alterations in precipitation and high interannual variability in semi-arid and arid regions. The seasonal variability in the study region (cp. Fig. 6) shows two peaks in water availability during the year, a high spring peak which is caused by snow melting and a minor peak in summer. For example in Mongolia the highest precipitation rates are during the summer months. In this study no shift in the seasonal variability of modelled water availability could be found, except ECHAM5 which does not show the second peak during July. The spring peak increases for all scenarios and GCMs until 2100, but with an earlier and sharper rise. In the case of IPSL-CM4 and CNRM-CM3 also the second peak during the summer increases. 


\section{Conclusions}

In this study the hydrology model WaterGAP3 has successfully been applied in order to analyse the water resources of Central Asia, driven by daily and monthly WATCH forcing and driving data. Generally, an increase in mean annual water availability was found in the scenario analyses. This increase might be overestimated - especially for the trends to wetter conditions- because the baseline was simulated with observed data and not with the GCM baselines. Also, an offset between observed baseline and modelled scenario climate data has been evident.

Not only today's wetter regions in Central Asia, such as the Pamir and Tien Shan Mountain ranges feature this increase in water availability but also arid regions, e.g. Taklamakan, show an increasing trend. In contrary, the Aral Caspian Depression has a robust trend to dryer climate conditions until 2100. In case of the three applied GCMs CNRMCN3 shows the highest increase in water availability for both scenarios A2 and B1, whereas ECHAM5 leads to the driest conditions. Our results for the study region also show that the range between the different GCMs is larger than between the emission scenarios A2 and B1.

Seasonal changes in runoff characteristics could be encountered only for ECHAM5 during the summer. Also, according to this study the spring and summer runoff peaks are expected to significantly increase, especially for the CNRMCM3 model output.

Further work needs to be done to verify the results obtained for the scenario period. In detail, the results should be analysed in the context of regional climate classifications e.g. Köppen-Geiger, or elevation. Also, future changes of major hydrological events, such as droughts and floods, with their frequency, duration and occurrence, are important for the study region and should be examined. Furthermore, the impacts of land-use change and water uses on the water resources and future conditions in Central Asia are of high importance, in particular for the regions with growing population density and/or anthropogenic water abstractions.

Acknowledgements. The authors would like to thank the GRDC for the gratuitous provision of observed river runoff data and the EU-FP6-WATCH project (Contract number GOCE 036946) for providing the climate data. This work has been supported by the BMBF project MoMo (Integrated Water Resources Management in Central Asia - Model Region Mongolia, FKZ: 033L003E).

Edited by: K. Schneider and S. Achleitner

Reviewed by: I. Pohle and one anonymous referee

\section{References}

Alcamo, J. M., Döll, P., Henrichs, T., Kaspar, F., Lehner, B., Rösch, T., and Siebert, S.: Development and testing of the WaterGAP2 global model of water use and availability, Hydrolog. Sci. J., 48, 317-337, 2003.

aus der Beek, T., Flörke, M., Lapola, D. M., Schaldach, R., Voß, F., and Teichert, E.: Modelling historical and current irrigation water demand on the continental scale: Europe, Adv. Geosci., 27, 79-85, doi:10.5194/adgeo-27-79-2010, 2010.

aus der Beek, T., Voß, F., and Flörke, M.: Modelling the impact of Global Change on the hydrological system of the Aral Sea basin, Phys. Chem. Earth, 36, 684-695, 2011.

Batimaa, P., Myagmarjav, B., Batnasan, N., Jadambaa, N., and Khishigsuren, P.: Urban water vulnerability to climate change in Mongolia. Ministry of Nature, Environment and Tourism, Water Authority, Ulaanbaatar, 78 pp., 2011.

Bucknall, J., Klytchnikova, I., Lampietti, J., Lundell, M., Scatasta, M., and Thurman, M.: Irrigation in Central Asia: Social, Economic and Environmental Considerations, World Bank report, 104 pp., 2003.

Cowan, P. J.: Geographic usage of the terms Middle Asia and Central Asia, J. Arid. Environ., 69, 359-363, 2007.

Curtis, G. E.: Kazakhstan, Kyrgyzstan, Tajikistan, Turkmenistan, and Uzbekistan: Country Studies (Area Handbook Series), Claitors Pub Division, 570 pp., 1997.

Döll, P., Kaspar, F., and Lehner, B.: A global hydrological model for deriving water availability indicators: model tuning and validation, J. Hydrol., 270, 105-134, 2003.

EDB (Eurasian Development Bank): Impact of Climate Change to water resources in Central Asia, Almaty, Kazakhstan, 44 pp., available at: http://www.vinokurov.info/assets/files/ EDB\%20Report\%206\%20climate\%20eng.pdf, 2009.

Flörke, M., Kynast, E., Bärlund, I., Eisner, S., Wimmer, F., and Alcamo, J.: Domestic and industrial water uses of the past 60 years as a mirror of socio-economic development: A global simulation study, Global Environ. Change, in press, 2012.

Geng, S., Penning, F. W. T., and Supit, I.: A simple method for generating daily rainfall data, Agr. Forest Meteorol., 36, 363376, 1986.

Hagemann, S., Chen, C., Haerter, J. O., Heinke, J., Gerten, D., and Piani, C.: Impact of a statistical bias correction on the projected hydrological changes obtained from three GCMs and two hydrology models, J. Hydrometeorol., 12, 556-578, 2011.

Hagg, W., Braun, L. N., Kuhn, M., and Nesgaard, T. I.: Modelling of hydrological response to climate change in glacierized Central Asian catchments, J. Hydrol., 332, 40-53, 2007.

ICG (International Crisis Group): Central Asia: Water and Conflict, ICG Asia Report N34, Osh/Brusseles, 39 pp., 2002.

IPCC (Intergovernmental Panel on Climate Change): Emissions Scenarios, Nebojsa Nakicenovic and Rob Swart (Eds.), Cambridge University Press, UK, 570 pp., 2000.

Krause, P., Boyle, D. P., and Bäse, F.: Comparison of different efficiency criteria for hydrological model assessment, Adv. Geosci., 5, 89-97, doi:10.5194/adgeo-5-89-2005, 2005.

Lehner, B., Verdin, K., and Jarvis, A.: New global hydrography derived from spaceborne elevation data, EOS T. Am. Geophys. Un., 89, 93-94, 2008.

Lioubimtseva, E. and Henebry, G. M.: Climate and environmental change in arid Central Asia: Impacts, vulnerability, and adapta- 
tions, J. Arid. Environ., 73, 963-977, 2009.

Malsy, M., aus der Beek, T., Eisner, S., Kynast, E., and Flörke, M.: Vulnerability of Central Asian water resources to climate variability, IWA 1st Central Asian Regional Young and Senior Water Professionals Conference, 22-24 September 2011, Almaty, Kazakhstan, Conference Proceedings, 103-114, 2011.

Marchenko, S. S., Gorbunov, A. P., and Romanovsky, V. E.: Permafrost warming in the Tien Shan Mountains, Central Asia, Global Planet. Change, 56, 311-327, 2007.

Menzel, L., aus der Beek, T., Törnros, T., Wimmer, F., and Gomboo, D.: Hydrological impact of climate and land-use change - results from the MoMo project, in: International Conference "Uncertainties in water resource management: causes, technologies and consequences", edited by: Basandorj, B. and Oyunbaatar, D., IHP Technical Documents in Hydrology No. 1, UNESCO Office, Jakarta, 15-20, 2008.

O'Hara, S. L.: Lessons from the past: water management in Central Asia, Water Policy, 2, 365-384, 2000.

Piani, C., Weedon, G. P., Best, M., Gomes, S. M., Viterbo, P., Hagemann, S., and, Haerter, J. O.: Statistical bias correction of global simulated daily precipitation and temperature for the application of hydrological models, J. Hydrol., 395, 199-215, 2010.

Ragab, R. and Prudhomme, C.: Climate Change and Water Resources Management in Arid and Semi-arid Regions: Prospective and Challenges for the 21st Century, Biosyst. Eng., 81, 3-34, 2002.

Schulze, K., Hunger, M., and Döll, P.: Simulating river flow velocity on global scale, Adv. Geosci., 5, 133-136, doi:10.5194/adgeo-5133-2005, 2005.

Verzano, K.: Climate change impacts on flood related hydrological processes: Further development and application of a global scale hydrological model, reports on Earth System Science, 71-2009, Max Planck Institute for Meteorology, Hamburg, Germany, 166 pp., available at: http://www.mpimet.mpg.de/fileadmin/ publikationen/Reports/WEB_BzE_71_verzano.pdf, 2009.
Verzano, K. and Menzel, L.: Hydrology in Mountain Regions: Observations, Processes and Dynamics, IAHS-Publication 326, Snow conditions in mountains and climate change - a global view, 147-154, 2009.

Weedon, G. P., Gomes, S., Viterbo, P., Österle, H., Adam, J. C., Bellouin, N., Boucher, O., and Best, M.: The WATCH forcing data 1958-2001: a meteorological forcing dataset for land surfaceand hydrological-models, WATCH Technical Report Number 22, 41 pp., 2010.

Weedon, G. P., Gomes, S., Viterbo, P., Shuttleworth, W. J., Blyth, E., Österle, H., Adam, J. C., Bellouin, N., Boucher, O., and Best, M.: Creation of the WATCH Forcing Data and Its Use to Assess Global and Regional Reference Crop Evaporation over Land during the Twentieth Century, J. Hydrometeorol., 12, 823-848, 2011.

Worden, R. L. and Savada, A. M.: Mongolia: A Country Study (Area Handbook Series), Claitor's Law Books and Publishing Division; 2nd Edn., 320 pp., 1991.

Yu, F., Price, K. P, Ellis, J., and Shi, P.: Response of seasonal vegetation development to climatic variations in eastern central Asia, Remote Sens. Environ., 87, 42-54, 2003.

Zwolsman, J. J. G., van Vliet, M., Bonte, M., Gorski, N., Flörke, M., Eisner, S., and Ludwig, F.: Water for utilities: Climate Change impacts on water quality and water availability in Europe, WATCH Technical Report 55, 49 pp., 2011. 